\title{
EFFECT OF ENZYMATIC PREPARATIONS ON IMPROVEMENT OF ENERGY UTILIZATION IN BROILER CHICK DIETS 2. CANOLA SEED
}

\author{
Sayed, A. M. Shabaan; Mohammed, S. Bahnas"; Mohammed, A. A. Abdel- \\ Mageed and El-Kamash, E.M. \\ Animal Prod. Res. Inst., Agric. Res. Center, Ministry of Agric., Doki, Giza, Egypt. \\ "Poultry Production Dept, Fac. of Agric., Fayoum Univ., Fayoum, Egypt.
}

\begin{abstract}
:
An experiment was conducted to study the possibility of partially replacing Soybean meal with Full-fat canola seeds (FFCS) with/without multicarbohydrase enzymes and its effect on growth performance, some carcass traits, some blood serum parameters and economical efficiency. A total number of 390 unsexed day-old Arbor-Acres broiler strain chicks were equally divided into 13 groups of similar mean body weight of 3 replicates each. An experimental corn-soybean meal starter and finisher basal diets were formulated in which dietary protein was replaced by FFCS protein at replacement ratios of 5, 10, 15 and $20 \%$. Diets were formulated to be iso-nitrogenous and iso-caloric being 23\% CP \& $3000 \mathrm{kcal} \mathrm{ME} / \mathrm{kg}$ for the starter diet and 20\% CP \& $3100 \mathrm{kcal}$ $\mathrm{ME} / \mathrm{kg}$ for the finisher diet. Thirteen dietary treatments were compared. One treatment consisted of the basal diet without FFCS (positive control diet). Four treatments consisted of the positive control diet supplemented with 5, 10, 15 or $20 \%$ FFCS without enzyme supplementation (negative control diets). Eight additional treatments consisted of the negative control diets supplemented with either Zympex $^{\circledR} 008$ or Xylam ${ }^{500}$ enzyme products at a level of $0.05 \%$. Live growth performance, carcass characteristics, some blood serum parameters, sensory evaluation of cooked meat and economical efficiency were determined. From the nutritional and economical point of view, it was observed that using FFCS up to $20 \%$ in both starter and finisher broiler diets supplemented with Zympex ${ }^{\circledR} 008$ enzyme product at a level of $0.05 \%$ has no detrimental effect on broiler chick's growth performance and gave the best economical efficiency.
\end{abstract}

Key words: Canola seeds, performance, slaughter, carcass, blood, sensory economic, broiler.

\section{INTRODUCTION}

There is growing interest within feed industry to use full-fat oilseeds in poultry diets. Canola seeds (Brassica napus, L.) were planted successfully in Egypt lands. This seasonal winter oil crop was proven to resist drought and can be planted in semi arid regions (Leela et al., 2002). Brassica Napus is the best one of Canola types since its component have been altered through genetic selection which markedly reduced its detrimental components, erucic acid and the glucosinolates to a negligible level and to less than $20 \mu \mathrm{g} / \mathrm{g}$, (Leeson and Summers, 2001). These levels are low enough to be of little or no harm to poultry. Full-fat canola seed (FFCS) contains approximately $40 \%$ oil and 22\% protein and is, therefore, a valuable source of energy and protein for poultry diets (Leeson et al., 1978; Shen et al., 1983; Salmon et al., 1988) when it is

Fayoum J. Agric. Res. \& Dev., Vol.22, No.1, January, 2008 
economically priced. In addition, seeds are often available locally, and in the intact form, they are more resistant to oxidation and can be more easily handled in on-farm feed mills compared with other ordinary fat sources (Leeson et al., 1978; Sim et al., 1991). Moreover, Ajuyah et al., (1991) reported that canola seed oil is an excellent source of $\alpha$-linolenic acid (8 to $12 \%$ ).

Summers et al. (1982) reported that feeding full-fat canola seed to broiler chickens resulted in depressed fat use and BW gain. Such reduced energy use from canola seed has been suggested to be due to the lower oil availability, resulting from the oil-encapsulating effect of the cell wall polysaccharides (Lee et al., 1991). Grinding is used to disrupt the cell wall structure of feedstuffs to increase the exposure of nutrients to the animal's digestive enzymes. Although the conventional grinding process has positive effects on seed rupture and cell wall disruption, some portion of the oil may still be encapsulated by the cell wall structure and may require enzyme supplementation for optimum energy use of full-fat canola seed. However, because of the high-oil content and the small seed size, the grinding of canola seeds is a difficult procedure, as the sieves in the hammer mill can easily become plugged. When seeds are premixed with cereal grains to overcome this problem, grinding may still be insufficient for an effective disruption of seed structure. Consequently, the nutrient-encapsulating effect of the cell walls may not be overcome by poultry, as they lack enzymes to digest polysaccharides of the cell walls.

The successful use of enzymes in cereal-based diets (Chesson, 1993) has stimulated interest in supplementation carbohydrase enzymes to target cell wall/nonstarch polysaccharides (NSP) of feedstuffs in poultry diets. Therefore, the goal of the current research is to investigate the effectiveness of carbohydrase enzymes in improving energy use from full-fat canola seed, thus enhancing its feeding value for poultry.

\section{MATERIALS AND METHODS}

\section{Experimental birds and housing}

Three hundred and ninety unsexed day-old Arbor-Acres broiler strain chicks were used in a 42 day growing trial. Chicks were individually wing-banded, weighed, and randomly distributed into 13 experimental groups of similar mean body weight $(45.22 \pm 0.18 \mathrm{~g} / \mathrm{chick})$ of 30 chicks each, which consists of 3 replicates of 10 chicks each. Chicks were housed in galvanized wire cage batteries.

\section{Experimental diets}

An experimental corn-soybean meal starter and finisher basal diets were formulated in which SBM was replaced by FFCS at ratios of 5, 10, 15 and 20 $\%$. Diets were formulated to be iso-nitrogenous and iso-caloric being $23 \% \mathrm{CP}$ \& $3000 \mathrm{kcal} \mathrm{ME} / \mathrm{kg}$ for the starter diets and $20 \% \mathrm{CP} \& 3100 \mathrm{kcal} \mathrm{ME} / \mathrm{kg}$ for the finisher diets. The experimental diets were formulated to cover the recommended nutrient requirements (NRC, 1994). Dietary ME content was under recommended ME levels suggested by Arbor-Acres broiler nutrition guide. The composition and calculated chemical analysis of the experimental diets is presented in Table (1). 
EFFECT OF ENZYMATIC PREPARATIONS ON IMPROVEMENT...3

Table (1): The composition of the experimental starter and finisher diets.

\begin{tabular}{|c|c|c|c|c|c|c|c|c|c|c|c|}
\hline \multirow{3}{*}{\multicolumn{2}{|c|}{ Item, \% }} & \multicolumn{5}{|c|}{ Starter (1 -21 days) } & \multicolumn{5}{|c|}{ Finisher (22 - 42 days $)$} \\
\hline & & \multicolumn{5}{|c|}{ Level of FFCS } & \multicolumn{5}{|c|}{ Level of FFCS } \\
\hline & & $\mathbf{0 \%}$ & $5 \%$ & $10 \%$ & $15 \%$ & $20 \%$ & $\mathbf{0 \%}$ & $5 \%$ & $10 \%$ & $15 \%$ & $20 \%$ \\
\hline \multicolumn{2}{|c|}{ Yellow Corn, ground } & 51.95 & 52.68 & 48.40 & 43.69 & 36.26 & 58.38 & 58.86 & 58.13 & 51.97 & 45.97 \\
\hline \multicolumn{2}{|c|}{ Corn gluten meal $(62 \%$ CP) } & 6.75 & 8.20 & 9.40 & 10.75 & 11.60 & 4.40 & 6.00 & 7.40 & 8.45 & 9.50 \\
\hline \multicolumn{2}{|c|}{ Wheat Bran } & 0.00 & 0.00 & 3.80 & 7.25 & 14.00 & 0.00 & 0.00 & 1.00 & 6.30 & 11.40 \\
\hline \multicolumn{2}{|c|}{ Soybean meal (44\% CP) } & 35.00 & 30.00 & 25.00 & 20.00 & 15.00 & 30.00 & 25.00 & 20.00 & 15.00 & 10.00 \\
\hline \multicolumn{2}{|c|}{ Canola Seeds $(22.18 \%$ CP $)$} & 0.00 & 5.00 & 10.00 & 15.00 & 20.00 & 0.00 & 5.00 & 10.00 & 15.00 & 20.00 \\
\hline \multicolumn{2}{|c|}{ Dicalcium phosphate } & 1.70 & 1.60 & 1.31 & 1.10 & 0.70 & 1.60 & 1.60 & 1.50 & 1.10 & 0.80 \\
\hline \multicolumn{2}{|c|}{ Limestone } & 1.00 & 1.05 & 1.20 & 1.30 & 1.50 & 1.10 & 1.10 & 1.12 & 1.31 & 1.44 \\
\hline \multicolumn{2}{|c|}{ Common salt } & 0.40 & 0.40 & 0.40 & 0.40 & 0.40 & 0.40 & 0.40 & 0.40 & 0.40 & 0.40 \\
\hline \multicolumn{2}{|c|}{ Vegetable oil } & 2.75 & 0.60 & 0.00 & 0.00 & 0.00 & 3.70 & 1.60 & 0.00 & 0.00 & 0.00 \\
\hline \multicolumn{2}{|c|}{ Premix $^{*}$} & 0.30 & 0.30 & 0.30 & 0.30 & 0.30 & 0.30 & 0.30 & 0.30 & 0.30 & 0.30 \\
\hline \multicolumn{2}{|c|}{ DL-Methionine } & 0.10 & 0.08 & 0.07 & 0.05 & 0.05 & 0.11 & 0.09 & 0.06 & 0.04 & 0.03 \\
\hline \multicolumn{2}{|c|}{ L-Lysine } & 0.05 & 0.09 & 0.12 & 0.16 & 0.19 & 0.01 & 0.05 & 0.09 & 0.13 & 0.16 \\
\hline \multicolumn{2}{|l|}{ Total } & 100 & 100 & 100 & 100 & 100 & 100 & 100 & 100 & 100 & 100 \\
\hline \multicolumn{12}{|c|}{ Determined values (\%) } \\
\hline \multicolumn{2}{|c|}{ ME, kcal/kg } & 3006 & 3002 & 3000 & 3037 & 3007 & 3104 & 3101 & 3104 & 3105 & 3110 \\
\hline \multicolumn{2}{|l|}{$\mathbf{C P}$} & 23.04 & 23.01 & 23.02 & 23.03 & 23.03 & 20.00 & 20.04 & 20.01 & 20.01 & 20.00 \\
\hline \multicolumn{2}{|l|}{ CF } & 3.68 & 3.67 & 3.96 & 4.20 & 4.74 & 3.44 & 3.42 & 3.49 & 3.90 & 4.29 \\
\hline \multicolumn{2}{|l|}{ Ca. \% } & 0.87 & 0.87 & 0.87 & 0.88 & 0.89 & 0.87 & 0.87 & 0.87 & 0.87 & 0.87 \\
\hline \multicolumn{2}{|c|}{ Avail. P \% } & 0.46 & 0.45 & 0.45 & 0.45 & 0.45 & 0.43 & 0.44 & 0.44 & 0.43 & 0.43 \\
\hline \multicolumn{12}{|c|}{ Calculated values } \\
\hline \multicolumn{2}{|l|}{ Lys.\% } & 1.18 & 1.18 & 1.18 & 1.18 & 1.18 & 1.01 & 1.01 & 1.01 & 1.01 & 1.01 \\
\hline \multicolumn{2}{|c|}{ Meth. \% } & 0.51 & 0.51 & 0.51 & 0.51 & 0.52 & 0.47 & 0.47 & 0.45 & 0.45 & 0.45 \\
\hline \multicolumn{2}{|l|}{ Cyst. \% } & 0.40 & 0.42 & 0.47 & 0.51 & 0.58 & 0.35 & 0.37 & 0.40 & 0.46 & 0.51 \\
\hline Meth. + & Cyst. \% & 0.91 & 0.93 & 0.98 & 1.02 & 1.10 & 0.82 & 0.84 & 0.85 & 0.90 & 0.96 \\
\hline & Without enzymes & 195.20 & 184.60 & 177.70 & 168.30 & 166.60 & 185.50 & 180.30 & 176.70 & 170.60 & 168.10 \\
\hline $\begin{array}{c}\text { Cost } \\
\text { PT/kg) }\end{array}$ & With Zympex $^{\circledR 008}$ & & 189.50 & 182.60 & 173.20 & 171.50 & & 184.80 & 181.20 & 175.10 & 172.60 \\
\hline & With Xylam $^{500}$ & & 186.90 & 180.00 & 170.60 & 168.90 & & 181.90 & 178.3 & 172.20 & 169.70 \\
\hline
\end{tabular}

* The premix (Vit. \& Min. ) was added at a rate of $3 \mathrm{~kg}$ per ton of diet and supplied the following per kg of diet (as $\mathrm{mg}$ or I.U. per kg of diet): Vit. A 12000 I.U., Vit. D3 2000 I.U., Vit. E 40 mg, Vit. K3 4 mg, Vit. B1 3 mg, Vit. B2 6 mg, Vit. B6 $4 \mathrm{mg}$, Vit. B12 $0.03 \mathrm{mg}$, Niacin $30 \mathrm{mg}$, Biotin $0.08 \mathrm{mg}$, Pantothenic acid $12 \mathrm{mg}$, Folic acid $1.5 \mathrm{mg}$, Choline chloride $700 \mathrm{mg}, \mathrm{Mn} 80 \mathrm{mg}, \mathrm{Cu} 10 \mathrm{mg}$, Se $0.2 \mathrm{mg}$, I $40 \mathrm{mg}$, Fe $40 \mathrm{mg}$, Zn $70 \mathrm{mg}$ and Co 0.25mg.

** According to market prices of the year 2007.

Fayoum J. Agric. Res. \& Dev., Vol.22, No.1, January, 2008 
Tested Materials

Canola seed used in this study showed a composition of $7.10 \%$ moisture; $22.18 \% \mathrm{CP} ; 40.00 \%$ EE; $6.00 \% \mathrm{CF} ; 3.13 \%$ ash; $0.38 \% \mathrm{Ca} ; 0.38 \%$ avail. P; $0.54 \%$ Met.; $0.68 \%$ Cyst; $1.66 \%$ Lys and $4220 \mathrm{kcal}$. ME/kg. The enzymatic preparations used in this study were: 1) Zympex ${ }^{\circledR} 008$ which is a multicomponent enzyme preparation containing $\alpha$-galactosidase, $\beta$-mannanse, protease, amylase, $\beta$-glucanase, xylanase and cellulase. It is used in legumesrich diets (such as soy and canola meal) at a level of 500 gram Zympex ${ }^{\circledR 008}$ per ton of feed and 2) Xylam ${ }^{500}$ is an enzymatic preparation containing $\beta$-xylanase (1260 U) and $\alpha$-amylase (8000 U). It is used at a level of 500 gram per ton of feed.

\section{Experimental design and treatments}

Thirteen dietary treatments were compared. One treatment consisted of the basal diet without FFCS (a positive control diet). Four treatments consisted of the positive control diet supplemented with 5,10,15 and $20 \%$ FFCS without enzyme supplementation (negative control diets). Eight additional treatments consisted of the negative control diets supplemented with either Zympex ${ }^{\circledR 008}$ or Xylam ${ }^{500}$ at level of $0.05 \%$.

\section{Management}

Chicks were reared under similar management conditions. Ambient temperature was maintained at $34-35^{\circ} \mathrm{C}$ during the $1^{\text {st }}$ week and weekly decreased by $5 \mathrm{C}$ for the next 3 weeks. Birds received continuous artificial lighting at night during the whole experimental period. Mash feed and fresh clean tap water were available ad liblitum.

\section{Measurements and Data Collection}

Growth Performance:

Individual body weight (BW, g) and feed intake (FI, g/bird) were weekly recorded to determine body weight gain (BWG, g). Feed conversion ratio (FCR, $\mathrm{g}$ feed/g gain) and mortality rate (MR) \% were also calculated on weekly basis.

\section{Carcass Parameters}

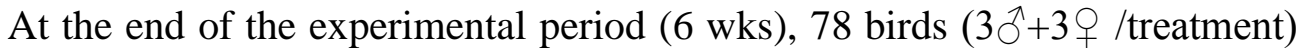
with BW similar to the mean were slaughtered to determine carcass characteristics. Obtained criteria were dressing, eviscerated carcass and breast $\%$. Abdominal fat was removed from the gizzard and abdominal region and individually weighed for each carcass. Also, the internal organs (liver, heart and gizzard) were individually separated and weighed.

\section{Sensory evaluation of cooked meat}

Three carcasses from each treatment were roasted in a conventional electric oven at $160{ }^{\circ} \mathrm{C}$ and were sensory evaluated. Ten practiced judges, who showed sensitivity in discrimination, were used as instrumental tools to investigate the differences in meat quality due to different treatments. Every judge rinsed his mouth with deionized water between tasting to clear the mouth of residual stimuli and lessen adaptation effects.

Judges determined the differences in color darkness, tenderness (the forces required to compress the meat between molar teeth on the first bite force necessary to attain a given deformation), juiciness (the degree and amounts of juice of the sample released upon chewing), chewiness (the number of chews required to reduce the sample to state ready for swallowing), flavor by mouth or taste (the sensation perceived by mouth), odour by smelling the meat that presented warm in a covered-petri dish and overall acceptability of different cooked meat. 


\section{EFFECT OF ENZYMATIC PREPARATIONS ON IMPROVEMENT...5}

\section{Blood serum parameters}

Seventy eight blood samples $(3 \hat{\partial} \& 3 \propto /$ treatment) were withdrawn from wing vein and serum was separated by centrifugation for 10 minutes $(3000 \mathrm{rpm})$ and stored in vials at $-20{ }^{\circ} \mathrm{C}$ for later analysis. Frozen serum was thawed and assayed to determine, on individual bases, some biochemical parameters in terms of total protein (TP), albumin (Alb) and triglycerides (TG) and cholesterol (Cho) by using commercial kits and Atomic Absorption Spectrophotometer, following the same steps as described by manufactures. Values were expressed as $\mathrm{mg} / 100$ ml. Serum TP was measured according to Henry (1974). Globulin (Glo) was calculated by the difference between serum TP and Alb, since the fibrinogen usually comprises a negligible fraction (Sturkie, 1986). The Alb/Glo ratio was also calculated.

\section{Chemical and statistical analysis}

Experimental diets were analyzed following procedures detailed by the Association of Official Analytical Chemists (AOAC 1990) for CP, CF, DM and EE. The NFE was calculated by difference. Metabolizable energy (ME) of experimental diets was calculated considering the ME values of different feed ingredients (NRC, 1994). Canola seeds and experimental diets were analyzed at Central Laboratory for Food and Feed, Agri. Res. Center, Ministry of Agric., Giza, Egypt.

Obtained data were expressed as means \pm standard error and statistically analyzed by analysis of variance according to Steel and Torrie (1980). Also, the General Linear Model (GLM) procedure of SPSS computer statistical program for MS Windows release 6.0 June 1993 was used. The significant means were ranked using Duncan's Range Test (Duncan, 1955) as outlined by Obi (1990). Statistical significance level was tested at probability of $\mathrm{p} \leq 0.05$.

\section{RESULTS AND DISCUSSION \\ Live growth performance:}

The results obtained for live growth performance in terms of BW, BWG, FI, FC and MR during the whole experimental period are shown in Table 2.

The initial BW of day-old broiler chicks was similar for all treatments. With regard to FFCS levels, it was noticed that feeding $5 \%$ FFCS -diets did not cause significant change in BW, BWG, FI, FCR and MR in comparison to $0 \%$ FFCS -diet.

Increasing FFCS level over 5 to $10 \%$ significantly decreased BW, BWG and FI values and increased MR \%, the only exception was for FCR that did not significantly differ. However, increasing FFCS level from 10 to $15 \%$ significantly decreased BW, BWG and FI values and increased MR \%, but it did not significantly affect FCR. Feeding $20 \%$ FFCS-diets gave the lowest BW, BWG and FI values and the highest MR \%. The only exception was for FCR that was similar in comparison to feeding either 10 or $15 \%$ FFCS-diet, but it was significantly higher than those of feeding either 0 or $5 \%$ FFCS-diet. These results are in agreement with the findings of Summers et al. (1982) who found that feeding $17.5 \%$ FFCS to broiler chickens resulted in depressed fat use and BW gain. Such reduced energy use from FFCS has been suggested to be due to the lower oil availability, resulting from the oil-encapsulating effect of the cell wall polysaccharides (Lee et al., 1991). Also, Roth Maier et al. (1988) reported that use of 5,10,15, 20 and $25 \%$ of FFCS in the broiler ration has negative effect on the chicken growth so that, body weight in experimental groups in comparison with control has showed $6.7-24 \%$ reduction. The present

Fayoum J. Agric. Res. \& Dev., Vol.22, No.1, January, 2008 
results disagreed with those of Najib and Al-Khateeb (2004) who found that FFCS concentration had no effect on FI and the depression of BWG was due to the toxicity from the erucic acid and glucosinolates. The MR in the current study are in disagreement with those of Leslie and Summers (1972) who observed no differences in MR when feeding diets fortified with FFCS.

Regarding enzymatic preparations, Zympex ${ }^{\circledR} 008$ significantly gave the highest BW and BWG values. The two exceptions were for FI that did not differ due to enzyme supplementation and MR\% that significantly reached the highest in case of enzyme-free diets followed by Xylam ${ }^{500}$-supplemented diets and then Zympex ${ }^{\circledR} 008$-supplemented diets. With respect to the interaction between FFCS level and enzymatic preparations, using either Zympex ${ }^{\circledR} 008$ or Xylam ${ }^{500}$ with 5\% FFCS diet did not exert any significant effect in BW, BWG, FI, FCR and MR as compared to the corresponding enzyme-free diets. On the other hand, supplementing Zympex ${ }^{\circledR 008}$ to diet containing 10,15 or $20 \%$ FFCS resulted in significant high $\mathrm{BW}, \mathrm{BWG}$ and $\mathrm{MR}$ as well as significant improvement in FCR as compared to the corresponding Xylam ${ }^{500}$ supplemented diets that caused similar values in these respects with the corresponding enzyme-free diets. However, adding either Zympex ${ }^{\circledR} 008$ or Xylam $^{500}$ to diet containing 10,15 or $20 \%$ FFCS diet did not cause any significant effect in FI as compared to the corresponding enzyme-free diets.

\section{Carcass parameters and chemical composition of breast muscle:}

The percentage of eviscerated carcass, dressing, breast and abdominal fat as well as the chemical composition of the breast muscle in terms of $\mathrm{CP}$ and EE are summarized in Table 3.

With regard to FFCS levels, it was noticed that feeding 5\% FFCS-diets did not cause significant change in both carcass parameters and chemical composition of breast muscle in comparison to 0\% FFCS-diet. Increasing FFCS level from 5 to $10 \%$ significantly decreased both carcass parameters and chemical composition of breast muscle, the only exception was for EE that did not significantly differ. However, there was no significant response obtained for increasing FFCS level from 10 to $15 \%$ in both carcass parameters and chemical composition of breast muscle except for dressing \% that was significantly decreased and abdominal fat $\%$ that was significantly increased. Feeding $20 \%$ FFCS-diets gave the lowest carcass parameters and chemical composition of breast muscle values except for abdominal fat and EE that reached the highest values. The present results are in harmony with the findings of Trefny $\boldsymbol{e t}$ al., (1986) who stated that blood parameters were not affected by partially or full replacement of SBM by rapeseed meal in broiler diets and Mohamed and ElHabbak, (1991) who found that plasma TP, TL and Cho values were not affected by feeding broilers on diets containing rapeseed meal. Furthermore, the increase in Cho. values observed in the present study are in good agreement with those of Hassan et al., (1992) who found that plasma lipids and Cho values increased with the increase of treated rapeseed meal in the diet and Dessouky, (1996) who revealed that total lipids and Cho values were significantly increased in case of feeding diets containing raw rapeseed meal.

Fayoum J. Agric. Res. \& Dev., Vol. 22, No.1, January, 2008 
EFFECT OF ENZYMATIC PREPARATIONS ON IMPROVEMENT...7

Table 2

Fayoum J. Agric. Res. \& Dev., Vol.22, No.1, January, 2008 
Sayed, A. M. Shabaan; et al.,

Table 3

Fayoum J. Agric. Res. \& Dev., Vol. 22, No.1, January, 2008 


\section{EFFECT OF ENZYMATIC PREPARATIONS ON IMPROVEMENT...9}

Regarding enzymatic preparations, Zympex ${ }^{\circledR} 008$ significantly gave the highest carcass parameters values except for abdominal fat that reached the lowest value. On the other hand, there was no significant response obtained for enzyme supplementation in chemical composition of breast muscle.

With respect to the interaction between FFCS level and enzymatic preparations, using either Zympex ${ }^{\circledR 008}$ or Xylam ${ }^{500}$ with $5 \%$ FFCS diet did not exert any significant effect in both carcass parameters and chemical composition of breast muscle as compared to the corresponding Xylam ${ }^{500}$ supplemented diets that caused similar values in these respects with the corresponding enzyme-free diets. However, supplementing Zympex ${ }^{\circledR 008}$ to diet containing 10,15 or $20 \%$ FFCS resulted in significant higher eviscerated carcass, dressing and breast meat as well as significant lower abdominal fat as compared to the corresponding Xylam ${ }^{500}$-supplemented diets that caused similar values in these respects with the corresponding enzyme-free diets. On the other hand, adding either Zympex ${ }^{\circledR 008}$ or Xylam $^{500}$ to diet containing 10, 15 or $20 \%$ FFCS diet did not cause any significant effect in chemical composition of breast muscle as compared to the corresponding enzyme-free diets.

Generally, FFCS contains seed hulls, concave particles, which have a tendency to stick to the inside of the digestive tract. From a technological point of view, if the gastrointestinal tract is torn during processing, then the black canola hulls can stick to the carcass causing it to be downgraded. The solution is to exclude FFCS from the feed during the last 5 days before market.

\section{Edible giblets:}

The percentage of edible giblets in terms of liver, heart, gizzard and total edible giblets are given in Table 4 . There was no significant response obtained for FFCS levels, enzyme supplementation or the interaction between FFCS level and enzymatic preparations in gizzard \%.

With respect to FFCS levels, it was noticed that feeding 5\% FFCS-diets did not cause significant change in edible giblets in comparison to 0\% FFCS-diet. Increasing FFCS level from 5 to 10 or 15 to $20 \%$ significantly decreased liver, heart and total edible giblets. However, increasing FFCS level from 10 to $15 \%$ did not exert significant effect in liver, heart and total edible giblets.

Concerning enzymatic preparations, Zympex ${ }^{\circledR} 008$ significantly gave the highest liver, heart and total edible giblets $\%$.

With respect to the interaction between FFCS level and enzymatic preparations, using either Zympex ${ }^{\circledR 008}$ or Xylam ${ }^{500}$ with 5\% FFCS diet did not exert any significant effect in edible giblets as compared to the corresponding enzyme-free diets. However, supplementing Zympex ${ }^{\circledR 008}$ to diet containing 10 , 15 or $20 \%$ FFCS resulted in significant higher liver, heart and total edible giblets $\%$ as compared to the corresponding Xylam ${ }^{500}$-supplemented diets that caused similar values in these respects with the corresponding enzyme-free diets.

\section{Sensory evaluation of cooked breast meat:}

Sensory evaluation values of cooked breast meat in terms of color darkness, tenderness, juiciness, chewiness, flavor by mouth (taste), odour and overall acceptance are illustrated in Tables 5. There was no significant response obtained for FFCS levels, enzyme supplementation or the interaction between $\mathrm{CM}$ level and enzymatic preparations in meat samples odour.

With respect to FFCS levels, judges easily distinguished the differences among the meat samples, judging that the meat sample of birds fed $64 \%$ FFCSdiets had the most darkness of color as well as the least tenderness, juiciness,

Fayoum J. Agric. Res. \& Dev., Vol.22, No.1, January, 2008 
Sayed, A. M. Shabaan; et al.,

chewiness, flavor by mouth (taste) and overall acceptance as compared to the other treatments.

Regarding enzymatic preparations, enzyme supplementation did not cause significant change in sensory evaluation.

With respect to the interaction between FFCS level and enzymatic preparations, adding either Zympex ${ }^{\circledR 008}$ or Xylam $^{500}$ to diet containing 5, 10, 15 or $20 \%$ FFCS diet did not cause any significant effect in sensory evaluation as compared to the corresponding enzyme-free diets.

Table (4): Edible giblets of broiler chicks fed different FFCS levels at $42 \mathrm{~d}$ of age

\begin{tabular}{|c|c|c|c|c|c|c|}
\hline \multicolumn{3}{|c|}{ Treatments } & \multicolumn{4}{|c|}{ Edible giblets ( \% of live BW) } \\
\hline $\begin{array}{c}\text { FFCS } \\
(\%)\end{array}$ & $\begin{array}{c}\text { ZYMPIX }^{008} \\
(\%)\end{array}$ & $\begin{array}{c}\text { Xylam }^{500} \\
(\%)\end{array}$ & Liver & Heart & Gizzard & Total \\
\hline 0 & 0 & 0 & $3.22 \pm 0.03^{\mathrm{a}}$ & $0.61 \pm 0.02^{\mathrm{a}}$ & $2.32 \pm 0.02$ & $6.15 \pm 0.10^{\mathrm{a}}$ \\
\hline \multirow{3}{*}{5} & 0 & 0 & $3.20 \pm 0.05^{\mathrm{a}}$ & $0.60 \pm 0.03^{\mathrm{a}}$ & $2.33 \pm 0.01$ & $6.13 \pm 0.12^{\mathrm{a}}$ \\
\hline & 0.05 & 0 & $3.21 \pm 0.02^{\mathrm{a}}$ & $0.61 \pm 0.01^{\mathrm{a}}$ & $2.30 \pm 0.03$ & $6.12 \pm 0.11^{\mathrm{a}}$ \\
\hline & $\mathbf{0}$ & 0.05 & $3.13 \pm 0.03^{\mathrm{a}}$ & $0.60 \pm 0.02^{\mathrm{a}}$ & $2.28 \pm 0.07$ & $6.01 \pm 0.13^{\mathrm{a}}$ \\
\hline \multirow{3}{*}{10} & 0 & $\mathbf{0}$ & $2.00 \pm 0.04^{\mathrm{b}}$ & $0.49 \pm 0.02^{\mathrm{b}}$ & $2.27 \pm 0.04$ & $4.76 \pm 0.11^{b}$ \\
\hline & 0.05 & $\mathbf{0}$ & $3.10 \pm 0.02^{\mathrm{a}}$ & $0.58 \pm 0.03^{\mathrm{a}}$ & $2.25 \pm 0.06$ & $5.93 \pm 0.10^{\mathrm{a}}$ \\
\hline & 0 & 0.05 & $2.01 \pm 0.02^{\mathrm{b}}$ & $0.50 \pm 0.02^{\mathrm{b}}$ & $2.27 \pm 0.05$ & $4.78 \pm 0.11^{b}$ \\
\hline \multirow{3}{*}{15} & 0 & $\mathbf{0}$ & $1.80 \pm 0.05^{\mathrm{b}}$ & $0.50 \pm 0.01^{\mathrm{b}}$ & $2.24 \pm 0.07$ & $4.54 \pm 0.13^{\mathrm{b}}$ \\
\hline & 0.05 & $\mathbf{0}$ & $3.02 \pm 0.02^{\mathrm{a}}$ & $0.59 \pm 0.02^{\mathrm{a}}$ & $2.23 \pm 0.02$ & $5.84 \pm 0.12^{\mathrm{a}}$ \\
\hline & o & 0.05 & $1.80 \pm 0.03^{b}$ & $0.49 \pm 0.01^{\mathrm{b}}$ & $2.22 \pm 0.01$ & $4.51 \pm 0.10^{b}$ \\
\hline \multirow{3}{*}{20} & 0 & $\begin{array}{l}0 \\
\mathbf{0}\end{array}$ & $1.11 \pm 0.03^{\mathrm{c}}$ & $0.40 \pm 0.02^{\mathrm{c}}$ & $2.21 \pm 0.03$ & $3.72 \pm 0.12^{\mathrm{c}}$ \\
\hline & 0.05 & 0 & $2.04 \pm 0.02^{\mathrm{b}}$ & $0.48 \pm 0.02^{\mathrm{b}}$ & $2.21 \pm 0.01$ & $4.73 \pm 0.10^{\mathrm{b}}$ \\
\hline & $\mathbf{0}$ & 0.05 & $1.12 \pm 0.04^{\mathrm{c}}$ & $0.40 \pm 0.02^{c}$ & $2.20 \pm 0.01$ & $3.72 \pm 0.11^{\mathrm{c}}$ \\
\hline \multicolumn{3}{|c|}{$\begin{array}{l}\text { FFCS (0) } \\
\end{array}$} & $3.22 \pm 0.04^{\mathrm{A}}$ & $0.61 \pm 0.02^{\mathrm{A}}$ & $2.32 \pm 0.02$ & $6.15 \pm 0.08^{\mathrm{A}}$ \\
\hline \multicolumn{3}{|c|}{ FFCS (5) } & $3.18 \pm 0.02^{\mathrm{A}}$ & $0.60 \pm 0.01^{\mathrm{A}}$ & $2.30 \pm 0.01$ & $6.09 \pm 0.06^{\mathrm{A}}$ \\
\hline \multicolumn{3}{|c|}{ FFCS (10) } & $2.37 \pm 0.01^{\mathrm{B}}$ & $0.52 \pm 0.02^{\mathrm{B}}$ & $2.26 \pm 0.03$ & $5.16 \pm 0.07^{\mathrm{B}}$ \\
\hline \multicolumn{3}{|c|}{ FFCS (15) } & $2.21 \pm 0.03^{\mathrm{B}}$ & $0.53 \pm 0.03^{\mathrm{B}}$ & $2.23 \pm 0.01$ & $4.96 \pm 0.09^{\mathrm{B}}$ \\
\hline \multirow{2}{*}{\multicolumn{3}{|c|}{ FFCS (20) }} & $1.42 \pm 0.02^{\mathrm{C}}$ & $0.43 \pm 0.03^{\mathrm{C}}$ & $2.21 \pm 0.02$ & $4.06 \pm 0.07^{\mathrm{C}}$ \\
\hline \multirow{2}{*}{\multicolumn{3}{|c|}{$\frac{\text { Without }}{\text { Zympex }}$}} & $2.28 \pm 0.01^{\mathrm{B}}$ & $0.50 \pm 0.02^{\mathrm{B}}$ & $2.26 \pm 0.03$ & $4.79 \pm 0.06^{\mathrm{B}}$ \\
\hline & & & $2.84 \pm 0.03^{\mathrm{A}}$ & $0.57 \pm 0.01^{\mathrm{A}}$ & $2.25 \pm 0.01$ & $5.66 \pm 0.05^{\mathrm{A}}$ \\
\hline \multicolumn{3}{|c|}{$\frac{\text { Zympex }}{\text { Xylam }^{500}}$} & $2.02 \pm 0.02^{\mathrm{B}}$ & $0.50 \pm 0.02^{\mathrm{B}}$ & $2.25 \pm 0.01$ & $4.76 \pm 0.08^{\mathrm{B}}$ \\
\hline
\end{tabular}

Means in the same column having different letters are significantly different at $p \leq 0.05$.

Fayoum J. Agric. Res. \& Dev., Vol. 22, No.1, January, 2008 
EFFECT OF ENZYMATIC PREPARATIONS ON IMPROVEMENT...11

Table 5

Fayoum J. Agric. Res. \& Dev., Vol.22, No.1, January, 2008 
Blood serum parameters:

Results concerning blood serum parameters in terms of total protein (TP), albumin (Alb), globulin (Glo), Alb/Glo ratio, triglycerides (TG) and cholesterol (Cho) are presented in Table 6. There was no significant response obtained for CM levels, enzyme supplementation or the interaction between FFCS level and enzymatic preparations in TP, Alb, Glo and Alb/Glo ratio.

With respect to FFCS levels, it was noticed that feeding 5, 10 or $15 \%$ FFCSdiets did not cause significant change in $\mathrm{TG}$ and Cho in comparison to $0 \%$ FFCS-diet. Increasing FFCS level to $20 \%$ significantly increased TG and Cho values.

Regarding enzymatic preparations, enzyme supplementation did not cause significant change in TG and Cho values.

With respect to the interaction between FFCS level and enzymatic preparations, adding either Zympex ${ }^{\circledR 008}$ or Xylam ${ }^{500}$ to diet containing 5, 10, 15 or $20 \%$ FFCS diet did not cause any significant effect in TG and Cho values as compared to the corresponding enzyme-free diets.

\section{Economical efficiency:}

Economical evaluation parameters for using FFCS in broiler diets in terms of feeding cost of the experimental diets, net revenue, economical efficiency $\left(\mathrm{EE}_{\mathrm{f}}\right)$ and relative economical efficiency $\left(\mathrm{REE}_{\mathrm{f}} \%\right)$ of meat production are listed in Table 7.

The $\mathrm{REE}_{\mathrm{f}} \%$ of broilers fed the diet supplemented with enzymes was better than those fed the control diet. These results are in agreement with those reported by El-Husseiny et al., (1995) and Soliman et al., (1996) who stated that enzyme preparations improved $\mathrm{EE}_{\mathrm{f}}$. Also, the present results are in agreement with those of Ghazalah et al., (2005) who reported that enzymes supplementation had a positive effect on reducing feed cost $/ \mathrm{kg} \mathrm{BWG}$ and $\mathrm{EE}_{\mathrm{f}}$.

From the nutritional and economical point of view, it could be concluded that using FFCS up to $20 \%$ in both starter and finisher broiler diets supplemented with Zympex ${ }^{\circledR} 008$ enzyme product at a level of $0.05 \%$ has no detrimental effect on broiler chick's growth performance and gave the best economical efficiency. 
EFFECT OF ENZYMATIC PREPARATIONS ON IMPROVEMENT...13

Table 6

Fayoum J. Agric. Res. \& Dev., Vol.22, No.1, January, 2008 
Sayed, A. M. Shabaan; et al.,

Table 7

Fayoum J. Agric. Res. \& Dev., Vol. 22, No.1, January, 2008 
EFFECT OF ENZYMATIC PREPARATIONS ON IMPROVEMENT...15

REFERENCES

A.O.A.C. (1990), Association of Official Analytical Chemists. Official Methods of analysis $15^{\text {th }}$ Ed., Published by Assoc. Office. Anal. Chem., Washington, D.C., USA.

Ajuyah, A.O., K.H. Lee, R.T. Hardin, and J.S. Sim. (1991). Changes in the yield and in the fatty acid composition of whole carcass and selected meat portions of broiler chickens fed full-fat oil seeds. Poult. Sci. 70:2304-2314.

Chesson, A. (1993). Feed enzymes. Anim. Feed Sci. Technol. 45: 65-97.

Dessouky, M.S. (1996). Nutritional studies on rapeseed and sunflower seed as feedstuffs in broiler rations. Ph.D. Thesis, Fac. Agric., Al-Azhar Univ.

Duncan, D.B. (1955). Multiple range and multiple F- test. Biometrics, 11: 1-42.

El-Husseiny, O.M., A.A. Ghazalah, H.M. Fayek and S.M. Abou El-Wafa (1995). Enzyme preparation, growth promoters and rumen contents in broiler diets. Egypt. Poult. Sci., 15: 205-232.

Ghazalah, A.A., A.H. Abd El-Gawad, M.S. Soliman and Amany. W. Youssef (2005). Effect of enzyme preparation on performance of broiler fed corn-soybean meal based diets. Egypt. Poult. Sci., 25: 295-316.

Hassan, F.M., H.M.S.Shoukry and A.H.Darwish (1992). The reliability of using body weight and some biochemical and physiological variables as indicators of the adverse effects of feeding broiler chicks on rapeseed meal. Egypt. Poult. Sci., 12: 31-56.

Henry, R. F. (1974). "Clinical Chemistry Principles and Technics" 2 nd Ed., Harper and Row, Hagerstein, MD. USA.

Lee, K., J.M. Olomu, and J.S. Sim. (1991). Live performance, carcass yield, protein and energy retention of broiler chickens fed canola and flax fullfat seeds and the restored mixtures of meal and oil. Can. J. Anim. Sci. 71:897-903.

Leela, A., S.A. Al-Khateeb and A.A. Al-Naeem, (2002). Response of some canola (Brassica napus, L.) varieties to drought. Final report, presented to the Deanship of Scientific Research of King Faisal University at AlHassa of Saudi Arabia.

Leeson, S. and J.D. Summers, (2001). Scott's Nutrition of the Chicken, 4 ed. University Books. P. O. Box 1326, th Guelph, Ontario.

Leeson, S., S.J. Slinger, and J.D. Summer. (1978). Utilization of whole Tower rapeseed by laying hens and broiler chickens. Can. J. Anim. Sci. 58:55-61.

Leslie, A.J. and J.D. Summers, (1972). Feeding value of rapeseed for laying hens. Can. J. Anim. Sci., 52: 563-566.

Mohamed, K.S. and M.S. El-Habbak (1991). Effect of feeding some rapeseed products on liver, heart, thyroid and plasma of broiler chickens. Egypt. Poult. Sci., 11: 303-319.

Najib, H. and S.A. Al-Khateeb, (2004). The Effect of Incorporating Different Levels of Locally Produced Canola Seeds (Brassica napus, L.) In the Diet of Laying Hen. Int. J. Poult. Sci., 3: 490-496.

National Research Council, N.R.C. (1994). Nutrient Requirements of Poultry. $9^{\text {th }}$ Revised. Ed., National Academy of Sciences Press, Washington, D.C., USA.

Obi, I.U., (1990). Statistical methods of detecting differences between treatment means. 2nd edn. Snaap Press, Enugu, Nigeria.

Fayoum J. Agric. Res. \& Dev., Vol.22, No.1, January, 2008 
Roth-Maier, A. Dora and M. Kirchgessner, (1988). Feeding of 00-rapeseed to fattening chicken and laying hens. Landwirtsch. Forschung, 41:140150.

Salmon, R.E., V.I. Stevens, and B.D. Ladbrooke. (1988). Full-fat canola seed as a feedstuff for Turkeys. Poult. Sci. 67:1731-1742.

Shen, H., J.D. Summers, and S. Leeson. (1983). The influence of steam pelleting and grinding on the nutritive value of canola rapeseed for poultry. Anim. Feed Sci. Technol. 8:303-311.

Sim, J., E. Nwokolo, and Z. Jiang. (1991). Modulation of plasma and tissue cholesterol and fatty acid composition by feeding flax and canola seeds and oils to rats. Can. J. Anim. Sci. 71:1207-1214.

Soliman, A.Z., I. Hassan, S. Abou El-Wafa and A.G. Abdellah (1996). Utilization of high fiber sunflower meal with /without commercial enzymes or stabilized rumen extract in broiler diets. Egypt. Poult. Sci., 16: 51-67.

SPSS (1993). SPSS Statistical software Package for the social sciences. 2 nd ed. HA33-N48. McGrow-Hill, Inc., USA.

Steel, R.G.D. and J.H. Torrie (1980). Principles and procedures of statistics: A Biometrical Approach 2 nd ed. McGraw-Hill Book Co., Inc., New York, USA

Sturkie, P. D. (1986). "Avain Physiology". $4^{\text {th }}$ ed. Springer-Verlag, New York, Inc. USA.

Summers, J. D., H. Shen, and S. Leeson. (1982). The value of canola seed in poultry diets. Can. J. Anim. Sci. 62:861-868.

Trefny, D., Z.Sova, S.Petkov, A.Funcikova, L.Fukal, P.Vrabec and M.Vit (1986). Biological aspects of using the (00) rapeseed meal for broiler feeding in Czechoslovakia, Seventh European Poult. Conf., Paris (1986) Vol. 1: 477-481 (Nutr. Abst. Rev. Series B., (1988) 58:312).

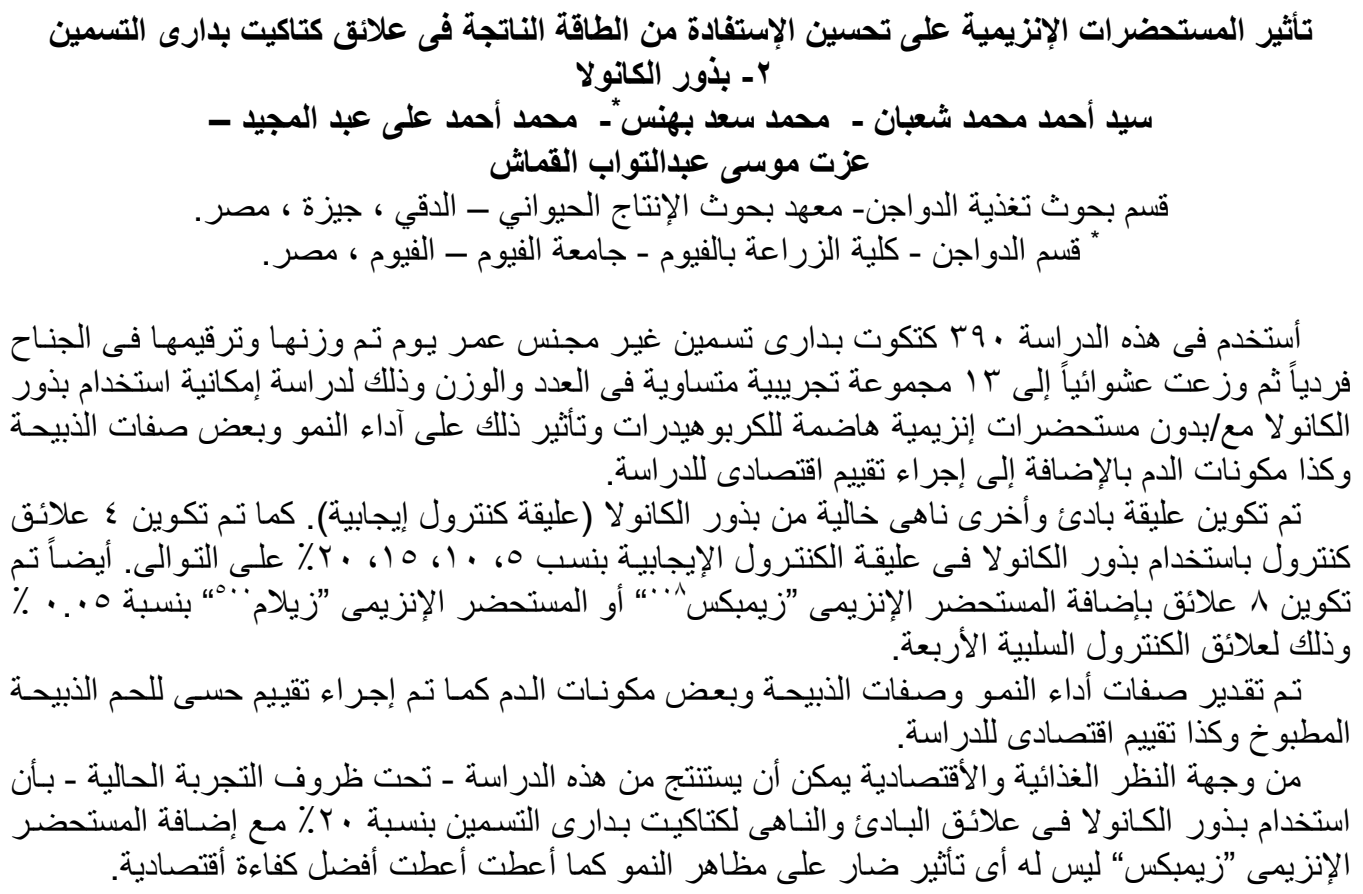

Fayoum J. Agric. Res. \& Dev., Vol. 22, No.1, January, 2008 